New Zealand Journal of Industrial Relations, 1992, 17(3): 283-299

\title{
The Australian Domestic Pilots' Dispute of 1989 and Its Implications: An Interpretation
}

\author{
John Burgess and Richard Sappey*
}

The 1989 domestic pilots' dispute in Australia provided a stark demonstration of the underlying conflict and tensions of the neo-corporatist Prices and Incomes Accord. The pilots proposed a wage increase outside of the Accord guidelines but of comparable magnitude with the wage increases received by senior executives within the airline sector and senior public servants. A protracted campaign saw the government and employers, with the tacit support of the ACTU, use a range of extreme measures against the Australian Federation of Air Pilots. Eventually, industrial peace was returned to the domestic airline sector. However, the costs, financial and emotional, of the dispute were considerable. The government restored industrial "order" but left considerable disquiet and division within the Australian trade union movement. The dispute established many important precedents for the business sector and the opposition Liberal/National Parties coalition in their push for labour market de-regulation in Australia.

\section{Introduction}

The Prices and Incomes Accord between the Australian Labor Party (ALP) and the Australian Council of Trade Unions (ACTU) has formed the backbone of economic policy for the term of the ALP's tenure in federal office since 1983. It provides for an orderly framework of consent between both parties over a range of mutual policy concerns - most notably wage determination. The Australian form of neo-corporatism has been characterised by a high degree of centralisation, the general absence of employers from the formal policy process and the preparedness of the ACTU to directly reform and compromise many long held wage determination and industrial relations principles and institutions.

The 1989 Australian domestic air pilots' dispute originated with a 30 percent wage claim served by the pilots on their employers. The reaction to this was condemnation by both the government and the ACTU for being outside of the national wage principles which at the time allowed for wage increases of up to six percent. A long and bitter dispute followed in which the Australian Federation of Air Pilots (AFAP) was severely weakened, about 600 Australian pilots accepted employment overseas while around 700 pilots became unemployed (Norington, 1990), overseas pilots and aircraft were brought 
into the domestic market, ${ }^{1}$ the government provided financial compensation to the domestic airline companies, Royal Australian Air Force (RAAF) planes were introduced into commercial operation, and common law provisions were implemented against the AFAP and its executive officers.

The dispute was salutary in terms of the extent to which the government and employers, with the support of the ACTU and the Industrial Relations Commission (IRC), used financial, military and legal pressures to break the industrial power of the AFAP. Singleton comments that the ACTU was prepared "to abandon some fundamental principles of the labour movement in defence of the Accord" $(1990,189)$. The dispute not only highlighted the inner tensions and contradictions of the Accord arrangement, it also illustrated that in the final analysis the Accord operates through intimidation, not consent, and to a large extent the Australian consensus incomes policy model is a one-sided and coercive tool of macroeconomic management.

This article outlines and assesses the implications of the 1989 Australian domestic air pilots' dispute. The following issues are addressed:

1. the nature of the Prices and Incomes Accord, especially its neo-corporatist foundations;

2. the methods used to settle the dispute, especially the resort to disciplinary measures as a means of enforcing national wage principles;

3. the strategies adopted by the major parties to the dispute;

4. the significance of the precedents established in the dispute, especially for a business sector keen on deregulating the labour market;

5. the demonstration that the principle of a "right" to industrial action in Australia only exists in spirit, not in law.

\section{The prices and incomes accord}

(a) History

The Prices and Incomes Accord was negotiated between the Australian Labor Party (ALP) and the ACTU prior to the Federal election of 1983. At the time a Coalition government initiated wages freeze was in place and the economy was in the middle of a recession. A consensus based incomes policy underpinning employment growth was seen by the signatories as an alternative approach to restrictive macroeconomic policy in the battle against stagflation. The rationale and protracted negotiations leading up to the Accord agreement are outlined by Singleton (1990). In the short term the Accord assisted the electoral aspirations of the ALP and offered the ACTU a return to wage indexation together with some input into the policy formulation process (Dabscheck, 1989: 45).

The original Accord (mark I) was not just about wages and macroeconomic management. It embraced a range of policy areas where the signatories were in agreement, including social welfare, health, industry development and prices supervision.

\footnotetext{
$1 \quad$ "... 1300 qualified Australians either languished in unemployment or - in a neat swap - left the country to take jobs that the immigrant pilots could be expected to seek in normal circumstances" (Norington, 1990: 244)
} 
To a large extent the Accord was seen as transposing the Swedish social consensus model to Australia (see Australia Reconstructed, 1987). ${ }^{2}$ Subsequently, the ALP was elected to office in 1983, and one of its first tasks was to obtain broader support for the Accord, especially from key business representatives. This it did through the National Economic Summit held in mid 1983. ${ }^{3}$ However, at the heart of the Accord's functioning remains the partnership between the government and the ACTU, and the central concern over wage determination.

Subsequently, the Accord has remained as one of the key economic policies of the government. Indeed, it is one of the few areas of economic policy where there remains significant disagreement between the government and the Liberal/National Parties opposition. It has stood the government well through three elections and has been renegotiated every year since 1983 .

\section{Neo-corporatist foundations}

Interest in corporatism as an economic and social strategy developed from the 1970 s in coincidence with the onset of stagflation. The "neo-corporatist" label has been applied to reflect the social democratic basis of the model and to distinguish it from the earlier right wing applications of corporatism such as those in Mussolini's Italy (Dufty and Fells, 1989: 131). In general terms neo-corporatism has come to refer to an approach to national decision making involving the hierarchically structured and disciplined representative bodies of labour and capital. In the contemporary applications of neocorporatism it is often an arrangement between organised labour and government (Dufty and Fells, 1989). Other groups, including employers, are included in the formal policy advisory process - for example, in Australia through their participation in tripartite bodies such as the Economic Planning and Advisory Council and the National Labour Consultative Council.

The successful implementation of contemporary neo-corporatist arrangements is associated with the presence of the following conditions:

1. national interest takes precedence over sectional interest;

2. sectional objectives (for example, wage increases) can be constrained and traded off via compensating policy adjustments by the government (for example, tax reductions) in support of the national interest;

3. partners to the agreement are fully representative of constituency interests and can negotiate on behalf of constituents;

4. partners can exercise control over membership behaviour and in turn protect the legitimacy of their peak status;

5. existing norms and institutional arrangements are open to compromise, negotiation and trade-off in the pursuit of collective goals; pluralist notions of the "rules of

2 The Accord also had origins in the ill-fated British social contract model of the late 1970 s. It is not surprising that the more durable Scandinavian model is presented as the Accord's genesis.

3 The National Economic Summit fragmented employers. The Confederation of Australian Industry support for both the Summit and the Accord saw the eventual formation of the Business Council of Australia representing the largest corporations. 
the game" can be compromised in pursuit of the collective good;

6. rational economic goals replace the ideological mores of partners as the dominant objective of the arrangement; neo-corporatism has been founded upon economic adversity, hence economic objectives become the major evaluative criteria for the arrangement (Head, 1990).

However, Winkler identifies a twin administrative dilemma for neo-corporatist arrangements, namely: "how to deal with conflict in a system where there is supposed to be one over-riding interest and how to avoid manifestations of coercion where people are supposed to co-operate spontaneously" (Winkler, 1977: 50).

While many of the conditions for the development of a neo-corporatist arrangement are present or have been developed in Australia under the Accord framework, Winkler's twin administrative "dilemmas" were vividly demonstrated by the pilots' dispute.

\section{(c) Competing interpretations}

The durability of the Accord in the face of adverse economic conditions, real wage reductions, growing unemployment and sustained political opposition has been remarkable. In 1985/86 Australia faced a severe external shock in the form of both a decline in the terms of trade coupled with an average currency depreciation of over 20 percent. Moreover, since 1983 average real adult award wages have declined in every year - the result has been one of the most significant redistributions of income from labour to capital this century. The operation of the Accord has coincided with a growing skewness in the distribution of income (Lombard, 1991) and an increase in the numbers in poverty in Australia (Saunders and Matheson, 1991). While significant job growth was achieved over 1983-88, the economy has subsequently entered a recession that has seen unemployment reach post World War II record rates. Additionally, the Accord has been subject to a campaign of constant condemnation from the "market rationalists" in the media and the business sector (see Wood, 1990) and has itself been instrumental in galvanising the formation of anti-corporatist and pro-market groups collectively labelled as the "New Right" who have played a very active role in Australian industrial relations over the past decade (see Dabscheck, 1989, ch.6).

There are at least six different interpretations of the Accord (see Stilwell, 1986, ch.3). Broadly, the views can be placed into three camps:

(i) those supportive of the Accord as a means towards securing better inflation and wage outcomes, for looking after the interests of those not in the workforce (the outsiders), and for assisting a small and exposed economy adjust to frequent external shocks, especially in commodity prices and the terms of trade (see Australia Reconstructed, 1987; Dixon and Keating, 1989). The Accord provides for a co-operation of interests between the State, labour and capital. The Accord demonstrates the advantages inherent within a neo-corporatist arrangement. It is a mechanism which reduces wasteful and counter-productive conflict and behaviour, such as that seen in past wage-price spirals in the economy (for example, 1982/83). The Accord is an essential tool of economic management, a means of reducing counter-productive class conflict and acts as a framework for implementing progressive reforms (Singleton, 1990, ch.11). 
(ii) those who oppose the centralist characteristics of the process, especially the inclusion of trade unions into the political policy process. Trade unions are seen to have too much power, wage increases are greater than those that would prevail under competitive market conditions, and unemployment is higher than it would otherwise be. The market rationalist critique is presented by Moore (1989) and periodically publicised by the many right wing think tanks which have mushroomed over the last ten years in Australia (see McGuiness, 1985). They oppose not only the Accord process but its implementation through the centralised IRC. Their model of industrial relations is founded upon enterprise based bargaining, in-house trade unions, the elimination of awards which establish minimum rates of pay and the introduction of considerable legal sanctions against trade union industrial action. ${ }^{4}$ Neo-corporatism is seen to be fundamentally at odds with liberalism and market individualism.

(iii) those who oppose the Accord as a sell-out of the interests of labour, see it as an institutionalised method of real wage reduction and income redistribution towards capital, and as a mechanism for eroding working conditions. Critical assessments of the Accord (see Bramble, 1989; Campbell, 1990; Burgess and Macdonald, 1990) see many of its arrangements and principles as eroding working conditions and trade unionism in Australia. Through being incorporated into the policy process, trade unions loose their independence and become locked into supporting a process which has undermined many of the basic tenets of trade unionism at a time in which trade union densities are rapidly falling (see Berry and Kitchener, 1989). Neo-corporatism is an instrument for the management of labour.

The domestic air pilots' dispute provides a very effective illustration of the Accord in practice and a test of the above rival interpretations. The argument adopted here is that neo-corporatism as practiced in Australia has largely been an instrument for the regulation and institutionalisation of labour. The major threat of the pilots was not the size of their claim, but the way they pursued it outside of the Accord process. ${ }^{5}$ This was not an industrial dispute over an irreconcilable wage claim, it was a direct challenge to the Accord framework and to the authority of the ACTU and government. The AFAP unwittingly exposed many of the tensions and contradictions associated with this framework and its underlying neo-corporatist foundations.

(d) The Accord in practice

While the Accord has remained in place since 1983, in substance and intent it has

4 Not surprisingly for such groups there has been considerable interest generated by the 1991 New Zealand industrial relations reforms.

5 The AFAP was not the first union to either directly or indirectly challenge the Accord. For example, in 1987, at the Special Unions' Conference, both the Miners' Federation and the Plumbers' and Gasfitters' Union refused to endorse the Accord national wage guidelines. However, unlike the AFAP, both of these unions continued to operate under the umbrella of the ACTU and did not instigate national industrial action in support of their claims. 
altered significantly. The original Accord arrangement incorporated a very wide policy agenda (see Stilwell, 1986, appendix). However, the periodic revisions of the Accord have concentrated exclusively on securing given nominal wage outcomes. Many of the original Accord objectives have been either ignored or directly contravened - for example, the complete withdrawal by the government from an active interventionist policy for industry development. ${ }^{6}$ In practice the Accord has become a wages policy and an integral component of macroeconomic policy management. Nominal wage outcomes are predictable and controllable for up to 12 months. The Accord has been presented as an essential component of a policy programme for the transformation of the Australian economy that includes other components such as industry deregulation, the privatisation of public assets, tariff reductions and the development of fiscal responsibility. In many respects, over the 1980 s, there is a similarity between this programme in Australia and that of the Btitish Thatcher government (see Rowthorn, 1989).

The six adjustments to the Accord since 1983 are all about securing wage outcomes consistent with macroeconomic objectives. In the process many long held wage principles (comparative wage justice, real wage maintenance) have been eroded. While international agencies such as the Organisation for Economic Co-operation and Development (1987) have been quick to praise the Accord as a success, the reality for many workers is that their real wage has fallen every year since 1983.

On the other hand prices and non-wage incomes have not been subject to such close regulation. The Prices Surveillance Authority, established in 1983 to support the Accord, does not have any powers of price control or regulation. It has been given a monitoring function with respect to "sensitive" prices such as petrol. Non-wage earners have been major beneficiaries of the Accord process. The profits share of income has increased while there has been a redistribution of income to the richest decile, especially from the middle income groups (Lombard, 1991). The salaries of corporate executives have increased by up to four times more than the wage increases received by Accord regulated wage earners (see Norington, 1990). Likewise, elite positions in the public sector have been granted significant wage and supplementary payments increases well beyond those received by the average wage earners - senior public servants, executive officers in tertiary education institutions, politicians, and judges. Those with capital have been beneficiaries of record real interest rates. At the same time the income tax rates for companies and the top income earners have been reduced.

\section{The pilot's dispute and neo-corporatism}

In practice the Accord has been one sided in its regulation of wages and control over trade unions. It has operated as an instrument of macroeconomic management and has been used to pursue many of those goals associated with a rational economic policy agenda. Neo-corporatism, Australian style, has exercised the type of control and discipline over trade unions that in other countries such as the UK (and more recently New Zealand)

$6 \quad$ The government did develop specific industry plans for steel, motor vehicles and heavy engineering. However, since 1983 the direction of industry policy has been towards an elimination of all forms of industry assistance. The March 1991 industry statement announced an acceleration in the reduction in tariffs. 
has required direct confrontation and conflict between government and trade unions.

The Australian pilots' dispute illustrated that the Labor Government was prepared to go much further than those identified on the political right in dealing with problem trade unions and in enforcing a centralist wages target. The AFAP directly challenged the basis of the Accord. It ignored the ACTU and the centralised wage determination process sanctioned by the IRC. It pointed out the contradiction of the restraint applying to wage earners but not to non-wage earners, and the different rules applying to "elite" wage earners such as senior public servants and the judiciary. For the pilots to have succeeded would have demonstrated a dangerous precedent to others in the workforce, and would have placed the peak leadership position of the ACTU in jeopardy. The other tension of the AFAP action was that it exposed the vacuous position of the opposition Liberal/National Parties' policy for wage determination and industrial relations. The opposition have favoured collective bargaining free from the constraints of centralised wage principles (see Howard, 1990). Although they have been consistent critics of the Accord and centralised wage determination, the opposition opposed the AFAP in its pursuit of a wage claim through collective bargaining and supported the actions of the government and ACTU.

As a background to the dispute, the following details are pertinent. First, the AFAP was not affiliated with the ACTU; in turn this made the ACTU position that much easier in its support of the government and employers. Second, the pilots were regarded in the trade union movement as mavericks and elite professionals (see Jamieson, 1990), and not in the traditional trade union mould - many pilots received more than five times average weekly earnings. Within the domestic airline industry, the pilots had a history of collective bargaining outside of the arbitration system and a willingness to engage in industrial action that inconvenienced the public (McEvoy and Owens, 1990: 92). ${ }^{7}$ Third, the domestic airline system in Australia at the time was a strictly regulated duopoly comprised of one government owned airline (Australian Airlines) and one privately owned airline (Ansett Airlines). In the past the AFAP had used this to its advantage since it could bargain with one airline and force successful claims onto the other airline. In turn the airlines were in a position of market dominance and were able to effectively regulate fares and to pass cost increases on to consumers. However, the problem in 1989 was that this arrangement was soon to finish. From November 1990 the industry was to be deregulated. The 1989 wage claim was the last chance for the AFAP to secure significant wage gains for members before deregulation. For the established domestic airline duopoly, the wage claim provided an opportunity for a show-down with the AFAP for the purpose of altering the pilots' award in time for deregulation. Fourth, the principal private sector airline, Ansett, was owned by companies associated with Rupert Murdoch and Sir Peter Abeles. They were both experienced in dealing with uncooperative trade unions through the direct involvement of their other companies in the UK Wapping print dispute. ${ }^{8}$ It goes without saying that the Australian media, with Murdoch's News Limited

7 The AFAP saw its claims as being on par with those of the non-regulated executive salaries, and as such it saw itself as not being constrained by national wage guidelines (McEvoy and Owens, 1990, 94).

8 The alleged close personal relationship between these key players in the dispute and the then Prime Minister Bob Hawke was a point the pilots emphasised and one that has been frequently publicised (see Pilger, 1989, ch.6). 
dominant, were totally opposed to the AFAP and its leadership throughout the pilot's dispute.

On July 26, 1989 the Federation served a 29.47 percent wage claim with the airline companies. The airlines refused to negotiate the claim since it was outside of the wage guidelines established under the Accord. The then guidelines provided for wage increases of up to six percent, except under special circumstances. In response, the executive of the AFAP directed on August 17 that members fly aircraft only between $9 \mathrm{am}$ and $5 \mathrm{pm}$. This predictably put the domestic airline system into chaos as many flights were cancelled and others were rescheduled to meet the reduction in flying hours. In response to a submission from the airlines, a federal tribunal of the IRC cancelled the award covering pilots on August 21. On August 23 the Federal Government authorised international airlines and the Royal Australian Air Force (RAAF) to carry domestic passengers. It also sanctioned domestic passenger traffic on international flights. The next day the domestic airlines filed writs for damages against pilots and on the same day the majority of pilots resigned from their jobs without notice. The airlines then began recruiting pilots from within Australia and overseas, offering them individual work contracts. On September 12 the Federal Government announced that it would compensate airlines for losses incurred because of the strike and for agreeing to employ staff who would have otherwise been stood down because of the dispute.

In the face of the combined forces against them, the AFAP offered to return to work on September 12 on the terms of their now cancelled award and on condition that the airlines negotiate with them over their pay claim. The airlines refused and in fact applied to the federal tribunal for a new pilots' award which involved increased flying time and reduced penalty rates. McEvoy and Owens (1990: 99) comment that "many of the benefits and conditions of employment which had been fought for by pilots over the years, such as integrated seniority lists and paternity leave, were gone". The IRC endorsed a new award on October 13 despite the fact that no trade union was party to it. As McEvoy and Owens commented, "the most striking fact about these awards was that there were no representatives of employees as parties" (1990: 100). On October 30 the airlines commenced civil action in the Supreme Court of Victoria against the AFAP and its officials; after an expedited hearing, on November 23 the case for the airlines was found to be proven, with the Federation and its officials found liable to damages of A $\$ 6.5 \mathrm{~m}$. Norington (1990: 170) observed that "it was extraordinary that a damages case of such proportions as the airlines could be tried, heard and decided within three months of the issue of writs and while the industrial dispute was still in progress".

A legal challenge to the above decision continues as does legal action in other areas such as the decision of the Federal Government to fast-track immigration procedures for the employment of foreign "strike-breakers". In May 1990 the IRC allowed the AFAP the right to represent its members before the federal tribunal. Only a fraction of the membership remains within the Australian domestic airline sector, despite some members obtaining employment with Compass Airlines. Many of the AFAP's former members are either employed overseas or outside of the industry, or are unemployed (Norington, 1990: 244).

The end result has been that the AFAP was not only defeated but severely 
weakened financially and in terms of membership. 9 The airline companies now employ pilots under individual contracts which involve poorer conditions than those in operation before the dispute. The original pilots' award was cancelled by the IRC and a new award was endorsed by the IRC without any trade union being a respondent to the award (McEvoy and Owens, 1990: 100). The government directly and indirectly compensated the airlines to the order of $A \$ 100 \mathrm{~m}$. In turn the defence forces were directly used to assist in settling the dispute. Finally foreign based airlines and pilots were directly used to solve a domestic labour dispute. All this occurred with the tacit support of the ACTU.

At no stage did the AFAP direct its members to strike action. Whether the limitation on flying hours constituted a strike is debateable. However, the point is that labour was not totally withdrawn. That the AFAP made several strategic blunders in its campaign and misread the extent of the organised forces opposed to it has been clearly documented by McDonald (1990). However, regardless of these tactical blunders, it did direct its members to work restrictive hours and it did direct its members to resign without notice (as was their contractual right), but no official strike as such ever occurred. This makes the government, ACTU and IRC response all the more extraordinary.

\section{Implications of the dispute}

What the pilots' dispute demonstrates is germane to an understanding of the conflicts and dangers present in a neo-corporatist strategy, and more importantly the wholesale participation in such a strategy by the trade union movement. There are profound implications from the pilots' dispute for individual unionists, individual trade unions and the ACTU through to the industrial relations system itself which, after all, has a vested constitutional authority to settle inter-state industrial disputes in Australia.

\section{(a) Trade unions}

Throughout the dispute the Federal Government asserted and presented itself as the dominant partner in the Accord. While attacking the stance of the AFAP, the ACTU provided implicit support for the actions of the government, though it did not itself take direct actions which could be seen as condoning the strike breaking activities of the government. On the other hand, the actions of the government won the approval of employers and served as a clear demonstration that it would not abide by any action which breached the rules of the Accord arrangements.

In the legal aftermath to the dispute, the ACTU has been conspicuous by its absence from the legal challenges by the AFAP to the various strike-breaking actions of the government and employers (see Smith, 1990). Increasingly the industrial relations legal framework is being superseded through the use of the law of torts and the secondary

9 Subsequently members did find employment with the new domestic airline Compass. However, the regrouping of the AFAP was short-lived since Compass was put into receivership in December 1991. 
boycott provisions of the Trade Practices Act (1974). ${ }^{10}$ Employers have seized upon these provisions and have achieved some notable victories over trade unions, including the AFAP (see Davis, 1991). Although there is a tradition of abhorrence by trade unions to the application of such tactics, the pilots dispute saw the government and employers, with the tacit support of the ACTU, using such tactics. ${ }^{11}$ More recently, these actions were legitimised by the $\mathrm{ILO}$, which in its consideration of the dispute resolved that the actions by the government and employers did not infringe convention 87 on the freedom of association since the social and economic consequences of the AFAP's action warranted the actions taken by employers and government (Moore, 1991). In turn this provided an important tactical precedent for employers to utilise and to bypass the industrial relations framework. Moore commented that "the resort by employers to the civil courts ... and just as significantly the threat to go to such courts, has been an important factor in reducing industrial disputation in the 1980s" (Moore, 1991).

The consequences for trade unions are that:

1. non-industrial legal intervention is an acceptable means for resolving industrial disputes and for disciplining labour, the AFAP and its executive are liable to damages of over $\$ 6 \mathrm{~m}$. to the domestic airlines despite the fact that they did not engage in strike activity - union funds can be confiscated and executive members held personally liable for any industrial activity which may affect the economic well being of employers and third parties. Such a tactic has been implicitly condoned by the government ${ }^{12}$, the ACTU and the ILO.

2. there is the danger of moving away from the traditional value system of the trade union movement. Established rank and file values - such as the right to pursue industrial action - have been challenged and overturned. Under such circumstances the internal discipline of the union movement is threatened since the moral foundations of this discipline have been undermined. If this is the case, then more pressure will be placed upon the neo-corporatist framework to impose a discipline on union membership in the absence of any moral imperative (see Smith, 1990).

The first consequence is the more immediate for individual unions and for union membership. Non-industrial legal intervention was increasingly being used to resolve industrial disputes before the pilots' strike (see Moore, 1991). What was unique about the pilots' dispute was that such a course of action was pursued by the ALP Government with the tacit support of the ACTU. It is no longer a tactic reserved for employers, but the

10 The use of common law provisions and the Trade Practices Act to resolve industrial disputes is increasing in Australia. Earlier applications included the Mudginberry, Dollar Sweets and Robe River disputes.

11 The Federal government did attempt in its Industrial Relations Act (1987) to restrict the access of employers to the common law resolution of industrial disputes. As an alternative the government proposed more extensive compliance sanctions within the industrial relations framework. The proposals were withdrawn by the government after strong and concerted opposition by employers and the media.

12 The Prime Minister did, belatedly, urge the companies to exercise restraint in the use of such common law action. 
domain of both government and ACTU to preserve neo-corporatist discipline. ${ }^{13}$ At a time in which the wage determination system is being formally decentralised with greater emphasis being given to collective bargaining, there must be considerable doubt on the ability of trade unions to effectively bargain with employers under the threat of common law penalties applying to any industrial action (see Taylor, 1990).

In the short term, the pilot's dispute has strengthened the position of the ACTU. First, it now has the ability to exercise coercive power over its affiliates in concert with government to protect the Accord arrangements. Individual unions are on notice if they wish to pursue claims outside of the negotiated Accord framework. Second, the relationship with government has been strengthened since the ACTU has demonstrated that it is prepared to compromise traditional values in order to deliver on the neo-corporatist bargain. Its position as a peak representative has been enhanced. Third, it has demonstrated to employers that it can deliver on its side of the neo-corporatist bargain under such an arrangement.

Individual unions in Australia are now more at risk than at any other time this century from the assertive application of the common law and other statutory devices applying to the resolution of industrial conflict. Individual claims and actions by unions and their officials now have to be very circumspect and comply with an array of common law, tort and trade practices law. The role of trade union officials has become increasingly proscribed within the neo-corporatist framework, their prime function is to implement and enforce the principles as determined by the ACTU and the government. ${ }^{14}$

It is not only from the legal system that unions find themselves increasingly at risk in Australia. The pilots' dispute demonstrated the lengths to which the government was prepared to go to settle the dispute on behalf of employers while retaining the integrity of the Accord. The government was prepared to call in the troops - in this case the RAAF in order to keep the industry going, for the first time since Prime Minister Chifley's decision to deploy the troops in the NSW coalfields in 1949. The government was prepared to allow international airlines to operate on domestic routes and to fast-track the employment of foreign pilots; that is, it was prepared to underwrite and sanction the use of "scab" labour. The government's third supportive action for employers was to directly and indirectly subsidise the domestic airline companies by around $A \$ 100 \mathrm{~m}$. - this involved reduced airport charges, subsidised use of the RAAF and direct compensation.

\section{The industrial relations system}

The authority and legitimacy of the IRC was being undermined before the pilots' dispute. First, as indicated previously, non-industrial law was increasingly being used by employers to settle industrial disputes and to discipline both unions and workers. Second,

13 "It is symptomatic of the corporatist nature of the Australian industrial relations system and of the ACTU's place in that system that it sided with the government, the airlines and the federal tribunal." (Smith, 1990, 251.)

14 Ironically, the principles associated with award restructuring provide for an increased role for trade union officials in negotiating workplace reforms and in reaching enterprise bargains. Since 1990 the system has moved away from centralised prescription towards decentralised negotiation. In this context the role and responsibilities of the trade union officials have greatly expanded. 
the Accord framework saw wage principles being determined and changed by the two Accord partners, with the IRC being excluded. Increasingly the function of the Commission was to ratify and oversee a timetable for the implementation of Accord principles. Third, from 1987 the Accord principles began to embrace a framework of increased collective bargaining between employers and unions to implement principles associated with the process of award restructuring. In this context the role envisaged for the IRC was that of formally ratifying such arrangements.

Throughout the airlines' dispute the Commission supported the actions of the government, ACTU and employers. It cancelled the award of the AFAP. It accepted the use of strike-breaking labour and it accepted the all encompassing character of the Accord arrangement. In turn it rejected the legitimacy of collective bargaining outside of the Accord framework.

The irony is that in its April 1991 decision the Commission rejected the terms of the 1991 Accord mark 6 wage determination arrangements that included provisions for productivity based collective bargaining. As a result the IRC found itself being placed in the same position as the AFAP. That is, being identified as a danger and threat to the sanctity of the Accord and its neo-corporatist foundations. Following the IRC's rejection of Accord mark 6 in April 1991, both the ACTU and the government indicated that they were prepared to support the Accord wages' package outside of the imprimatur of the IRC (see Green, 1991). Paradoxically the AFAP were punished for going outside of the Commission and for attempting to directly negotiate with employers. The Commission now found itself in the same ostracised position as the AFAP - it challenged the solidarity of the Accord wage principles. ${ }^{15}$

The Accord process has effectively removed the need for an industrial referee since wage principles are agreed upon before they arrive at the Commission. The enforcement function of the Commission has also been eroded with this role falling to the ACTU, the government and to employers through the array of non-industrial laws. In the airlines dispute the Commission was left no room to compromise or to negotiate an outcome acceptable to employers and the AFAP. The government and the ACTU had deemed that any outcome outside of the Accord guidelines was unacceptable, and that any action that enforced these guidelines was acceptable. The dispute was effectively resolved independently of the Commission. The combination of law suits, strike breakers, government financial support for employers and the industrial isolation of the AFAP by the ACTU effectively defeated the industrial action. The Commission was relegated to the role of a minor player. This process of the marginalisation of the Commission has subsequently continued. ${ }^{16}$

In the longer term the undermining of the Commission gives legitimacy to the agenda of employers and of the Coalition parties for a far more decentralised industrial relations system, perhaps along the lines of those industrial relations reforms introduced

15 Ironically the AFAP was one of the first groups to apply to the IRC for the discredited $2.5 \%$ wage increase under Accord mark 6.

16 There was a rift between the IRC and the government over the Commission's decision in April 1991 not to implement Accord wage principles. The rift has widened with a dispute over IRC members' salaries and the resignation of two IRC members in 1992. The government has also announced its intention of amending s.115 of the Industrial Relations Act in order to effectively remove from the IRC the power to vet and reject enterprise agreements. 
into New Zealand in 1991. Under these collective and contractual arrangements the role and importance of the Commission would be considerably diminished. Furthermore, the extreme measures of the government and ACTU in resolving the industrial dispute provide a strong precedent for any future coalition government. After all, they can claim that they are only following the lead of an ALP Government and the ACTU. When next a Coalition government takes office in Australia it has a considerable armoury of legal and policy precedents to discipline either the ACTU or individual unions. That the IRC has had a history of flexibility in its decisions and an ability to survive cannot be doubted. The pilots' dispute illustrated the IRC in its flexible mode. However, the survival ability of the IRC is beside the point. What was important was that survival of the Accord and the maintenance of the neo-corporatist arrangement took priority over the IRC.

\section{(c) The right to strike}

The pilots' dispute generated considerable discussion over the "right to strike", or more significantly the lack of any legal right to strike in Australia (see Green, 1990). Smith interpreted the success of the common law action against the AFAP as demonstrating "that there is no right to strike in Australia" (1990: 243). However, the pilots never formally went out on strike; their tactic was initially to reduce flying hours and then to subsequently resign en masse. Whether the AFAP formally engaged in strike action is a moot point, they were engaging in industrial action in pursuit of a wage claim. In the traditional industrial relations arena their tactic could be regarded as legitimate, and not even extreme, since the initial withdrawal of labour was only partial and air services were maintained. Their subsequent resignations did amount to an almost total withdrawal of labour, but they were no longer employees.

If the AFAP had officially endorsed a strike, would the collective response of the other parties have been any different? The authority of the Accord was still under threat and employers would still have been able to utilise non-industrial law remedies. It is very unlikely that the tactics used by the government and employers, or the outcome, would have been any different in the case of a formal strike.

Indeed, the pilots' dispute once more made explicit the absence of any right to engage in industrial action in Australia. No union or individual union members have any immunity from the legal consequences of engaging in industrial action, whether a stopwork meeting or a strike. The application of this principle was reinforced by the pilots' dispute, with the funds of the AFAP and the personal assets of its officials potentially available to settle the legal claims of employers and affected third parties.

Two interesting developments emerged in the aftermath of the dispute. First, the ILO deemed that the actions of the government were legitimate under convention 87 since the actions of the AFAP caused a great inconvenience to the public. This seems to circumscribe any application of rights or entitlements with respect to industrial action in Australia and elsewhere. ${ }^{17}$ Second, the government subsequently raised the possibility of legislating for a right to strike in order to provide some legal immunity for unions and

17 Smith (1990: 246) suggests that by cancelling the award and by making a new award to which no trade union was a party, the federal tribunal breached both convention 87 (freedom of association) and convention 98 (the right to organise). 
officials from common law action. ${ }^{18}$ The irony of this proposal was not lost on employers who quickly rejected it, citing the pilots' dispute as an example why there should be no such immunity (Eccleston, 1991). The actions of the government together with the implicit support of the ACTU in the pilots' dispute has effectively undermined any future claim for immunity from damages by trade unions in pursuit of their claims against employers.

\section{Conclusions}

The 1989 airline pilots' dispute was a watershed in Australian industrial relations. It demonstrated the commitment of the ACTU and the government to the neo-corporatist Accord framework. The AFAP had the potential to undermine this neo-corporatist framework and to provide a precedent for other unions whose real wage aspirations have been restrained through the operation of the Accord process since 1983. The dispute saw an unprecedented collective response by government, the ACTU and employers. It saw the most draconian set of actions in the post war period applied against a union and its membership, short of imprisonment. Moreover, it demonstrated the diminished role and status accorded to the Australian Industrial Relations Commission in terms of both its wage determination and industrial dispute resolution functions. The dispute also highlighted the absence in Australia of any legal right by trade unions to pursue industrial action over a wages claim.

The precedents established in the air pilots' dispute will undoubtedly haunt the ACTU and the IRC. The coalition parties and employers have an opportunity to use the same forces as those used by the government to ensure the implementation of their programme of industrial relations and labour market reform. Additionally, the need for a formal dispute resolution process must be questioned in the context of an absence of any legal right to engage in industrial action together with a range of common law constraints over industrial action.

The dispute highlights the inner tensions of neo-corporatist arrangements. Consensus, the collective interest and the authority of peak representatives in the end can only be maintained through some measures of discipline and coercion. It was only a matter of time before a union such as the AFAP challenged the hegemony of the Accord and the legitimacy of its principles.

\section{References}

ACTU/Trade Development Council. (1987), Australia Reconstructed, Canberra.

Berry, P. and Kitchener, G. (1989), Can Unions Survive?, Canberra, Building Workers Industrial Union.

18 Although the public position of the government remained firm throughout the pilots' dispute, several senior members such as ex Industrial Relations Minister Morris and the present incumbent, Senator Cook, have expressed a public view against the use of common law action in industrial disputes. 
Boreham, P. (1990), Corporatism, In C. Jennett and R. Stewart, Hawke and Australian Public Policy, Melbourne, Macmillan.

Bramble, T. (1989), Award Restructuring and the Australian Trade Union Movement: A Critique, Labour and Industry, 2(3): 372-398.

Burgess, J. (1990), The Australian Labour Market in the 1990s, Australian Quarterly, 62(3): 267-276.

Burgess, J. and Macdonald, D. (1990), The Labour Flexibility Imperative, Journal of Australian Political Economy, 27: 15-33.

Campbell, I. (1990), The Australian Union Movement and Post-Fordism, Journal of Australian Political Economy, 26: 1-26.

Crouch, C. (1977), Class Conflict and the Industrial Relations Crisis: Compromise and Corporatism in the Policies of the British State, London, Humanities Press.

Crouch, C. (1979), The Politics of Industrial Relations, Glasgow, Fontana/Collins.

Dabscheck, B. (1983), Of Mountains and Routes Over Them: A Survey of Theories of Industrial Relations, Journal of Industrial Relations, 25: 485-506.

Dabscheck, B. (1989), Australian Industrial Relations in the 1980s, Melbourne, Oxford University Press.

Davis, M. (1991), Vic Unions Hit for \$600,000, Australian Financial Review, March 22.

Dufty, N. and Fells, R. (1989), Dynamics of Industrial Relations in Australia, Sydney, Prentice Hall.

Dusevic, T. (1990), Superannuation Coverage Less than Government, ACTU Claim, Australian Financial Review, March 8.

Eccleston, R. (1991), Bosses Reject Right to Strike, The Australian, March 27.

Goldthorpe, J.H. (1984), The End of Convergence: Corporatist and Dualistic Tendencies in Modern Western Societies, In J.H. Goldthorpe (ed.), Order and Conflict in Contemporary Capitalism, Oxford, Clarendon.

Green, R. (1990), The Right to Strike, Sydney, Evatt Foundation.

Green, S. (1991), IRC Rebuffs ACTU, Government on Reform, The Australian, April 17.

Harrison, R.J. (1980), Pluralism and Corporatism: the Political Evolution of Modern Democracies, London, George Allen and Unwin. 
Head, B. (1988), The Labor Government and Economic Rationalism, Australian Quarterly, Summer: 466-477.

Head, B. (1990), Corporatism, In Summers, J., Woodward, D. and Parkin, A., Government, Politics and Power in Australia, Melbourne, Longman Cheshire.

Hearn, J. (1987), Corporatism Australian Style: the Prices and Incomes Accord, In Ford, G., Hearn, J. and Lansbury, R. (eds.), Australian Labour Relations: Readings, Melbourne, Macmillan, 4th ed.

Howard, J. (1990), The Liberal-National Parties' Industrial Relations Policy: Deregulation by Providing an Enterprise Focus, Economic and Labour Relations Review, 1(2): 34-47.

Jamieson, S. (1990), Captain McCarthy and the Temple of Doom: Trade Unions, the State and the Right to Strike, Brisbane, Australian Society of Labor Lawyers Conference.

Leach, R. (1988), Political Ideologies, Melbourne, Macmillan.

Lewis, P. and Spiers, D. (1990), Six Years of the Accord: An Assessment, Journal of Industrial Relations, 32(1): 53-68.

Lombard, M. (1991), Income Distribution in Australia 1983-1989, Economic Papers, 10(3): $52-63$.

McDonald, J. (1990), Industrial Relations Strategies in the Air Pilots' Dispute 1989, Economic and Labour Relations Review, 1(1): 121-144.

McEvoy, K. and Owens, R. (1990), The Flight of Icarus: Legal Aspects of the Pilots' Dispute, Australian Journal of Labour Law, 3(2): 87-129.

McGuiness, P. (1985), The Case Against the Arbitration System, Sydney, Centre for Independent Studies.

Moore, D. (1989), Industrial Relations and the Failure of the Accord: What Should be Done?, Australian Bulletin of Labour, June, 153-183.

Moore, D. (1991), Striking a Blow Against the Right to Strike, The Australian, March 20.

Norington, B. (1990), Executive Salaries Rise by up to 25 Percent, Sydney Morning Herald, April 9.

Norington, B. (1990), Sky Pirates: the Pilots' Strike that Grounded Australia, Sydney, ABC Books.

OECD (1987), Economic Surveys 1986/87: Australia, Paris.

Pilger, J. (1989), A Secret Country, London, Vintage. 
Rowthorn, R. (1989), The Thatcher Revolution, Economic Papers, 8(2): 1-22.

Saunders, P. and Matheson, G. (1991), An Ever Rising Tide? Poverty in Australia in the Eighties, Economic and Labour Relations Review, 2(2): 131-142.

Schmitter, P. (1979), Still the Century of Corporatism?, In P. Schmitter and G. Lehmbruch, Trends Towards Corporate Intermediation, Beverly Hills, Sage.

Schofield, J. (1989), Freezing History: Women Under the Accord, University of NSW, Industrial Relations Research Centre.

Singleton, G. (1990), The Accord and the Labour Movement, Melbourne, Melbourne University Press.

Smith, G. (1990), From Consensus to Coercion: the Australian Air Pilots' Dispute, Journal of Industrial Relations, 32(2): 238-153.

Stilwell, F. (1986), The Accord and Beyond, Sydney, Pluto.

Streeck, W. (1984), Neo-corporatist Industrial Relations and the Economic Crisis in West Germany, In Goldthorpe, J. (ed.), Order and Conflict in Contemporary Capitalism, Oxford, Clarendon.

Taylor, V. (1990), Politics and the Institutional Apparatus of Australian Industrial Relations in the Late 1980s, Journal of Australian Political Economy, 26: 27-46.

Wood, A. (1990), Why it's Time to Shoot the Accord, The Weekend Australian, July $14 / 15$.

Williamson, P. (1985), Varieties of Corporatism, Cambridge, Cambridge University Press.

Winkler, J. (1977), The Corporatist Economy: Theory and Administration, In Scase, R. (ed.), Industrial Society: Class, Cleavage and Control, London, Allen and Unwin. 